\title{
Rhenium Re-188 Etidronate
}

National Cancer Institute

\section{Source}

National Cancer Institute. Rhenium Re-188 Etidronate. NCI Thesaurus. Code C156698.

A synthetic compound containing the bisphosphonate etidronate (hydroxyethylidene diphosphonate, HEDP) labeled with rhenium Re188, a beta-emitting radioisotope with potential antineoplastic activity. Upon administration, Re-188 etidronate binds to hydroxyapatite in bone, delivering a cytotoxic dose of beta radiation to primary and metastatic bone tumors. The beta-radiation may provide localized anti-tumor radiotoxicity while sparing extramedullary bone marrow tissues. 